\title{
First Record of Pulaeus subterraneus Berlese, Male; with A Comparison between The Tritonymph Stage of The Two Sexes (Acri: Cunaxidae)
}

\author{
Mahmoud E. El-naggar ${ }^{1}$; Magda Kh. Megalli ${ }^{1}$; Aziza h. Omar ${ }^{2}$; \\ Mohammed M. El-Shazly ${ }^{2}$ and Mona M. Ghallab ${ }^{1}$ \\ ${ }^{1}$ Acarology Department, Plant Protection Research Institute, Agriculture research Center. \\ ${ }^{2}$ Entomology Department, Faculty of Science, Cairo University.
}

\begin{abstract}
The present paper deals with the description of the adult male Pulaeus subterraneus Berlese, which has never been recorded and described before. A comparative study between the tritonymph of male and female was undertaken. The different developmental stages were illustrated and described to show their morphological characters. The illustration of the adult female was displayed for comparison.
\end{abstract}

KEY WoRDS: Pulaeus subterraneaus, male, Cunaxidae, morphology.

\section{INTRODUCTION}

Members of family Cunaxidae are regarded as predators suppressing their associated phytophagous pest population on plants, in debris and in soil. Different species were recorded all over the world Berlese, 1888; Baker \& Hoffmann, 1948; Cooreman, 1954; Smiley, 1975 and Den Heyer, 1975 \& 1979). In 1981a, Den Heyer discussed the historical background of this family and its morphological and taxonomical features. In Egypt, some studies were carried out concerning their occurrence, biology and morphology of different species (Zaher et al., 1970; Zaher et al., 1975; Nassar, 1976; El-Bishlawy \& Rakha, 1983; Zaher, 1986; El-Khateeb, 1998 \& Khalil, 2000). Moreover the seasonal fluctuations in population of the three cunaxid mites, Pulaeus subterraneus Berlese, Coleoscirus simplex (Ewing) and Coleoscirus tuberculatus Den Heyer were investigated by Ghallab (2002), as well as some biological and morphological studies. The biological aspects and behavior of these cunaxid species were recorded during their life span and the different stages were illustrated and described.

\section{MATERIALS AND METHODS}

The alive mites of $P$. subterraneus were separated by modified Tullgren funnels from soil, weeds or leaf litter, collected from under different host plants and received in Petri-dishes filled with water. Adult females obtained from field were placed in a plastic vial, supplied with sufficient quantities of the nematode, Rhabditella muscicola Chitwood, as a prey, then, checked every day. Newly deposited eggs were transferred singly to plastic cells for rearing. Each newly hatched larva was monitored till reaching maturity. All stages of reared mite were cleared in Nesbitt's solution then mounted using Hoyer's medium on glass slides for description.

All the descriptions used of body structure and the chaetotaxy followed those of Smiley 1992.

\section{MORPHOLOGICAL CHARACTERS OF THE ADULT MALE}

\section{Subfamily: Cunaxoidinae Den Heyer}

Characteristics: Palp three segments, $\mathrm{L}_{4}$ present or absent, setae $\mathrm{hg}_{1}-\mathrm{hg}_{4}$ simple, shield may be smooth, punctuated or striated.

\section{Pulaeus subterraneus Berlese}

Eupalus subterraneus Berlese, 1916: 293; Thor \& Willmann, 1941: 183.

Cunaxoides subterraneus (Berlese) Baker \& Hoffmann, 1948: 245.

Dimensions:

\begin{tabular}{lccccccccc}
\hline \multirow{2}{*}{ Stage } & \multicolumn{2}{c}{ Idiosoma } & \multicolumn{3}{c}{ Length of } & \multicolumn{3}{c}{ Length of legs } \\
\cline { 2 - 12 } & length & Width & Hypo. & palp & Ch. $^{2}$ & I & II & III & IV \\
\hline Adult ${ }^{\lambda}$ & 236 & 130 & 92 & 60 & 80 & 136 & 120 & 146 & 160 \\
\hline Adult + & 320 & 194 & 116 & 68 & 110 & 180 & 160 & 184 & 206 \\
\hline TN 0 & 236 & 130 & 86 & 54 & 78 & 136 & 116 & 136 & 150 \\
\hline TN 0 & 290 & 168 & 112 & 64 & 104 & 168 & 158 & 178 & 196 \\
\hline DN & 226 & 146 & 80 & 48 & 74 & 130 & 114 & 140 & 146 \\
\hline PN & 204 & 140 & 76 & 44 & 68 & 124 & 108 & 130 & 134 \\
\hline Larva & 152 & 104 & 58 & 32 & 46 & 88 & 84 & 104 & \\
\hline
\end{tabular}

All measurements were given in microns. $(1=$ Hypognathum; 2 = Chelicera $)$ 

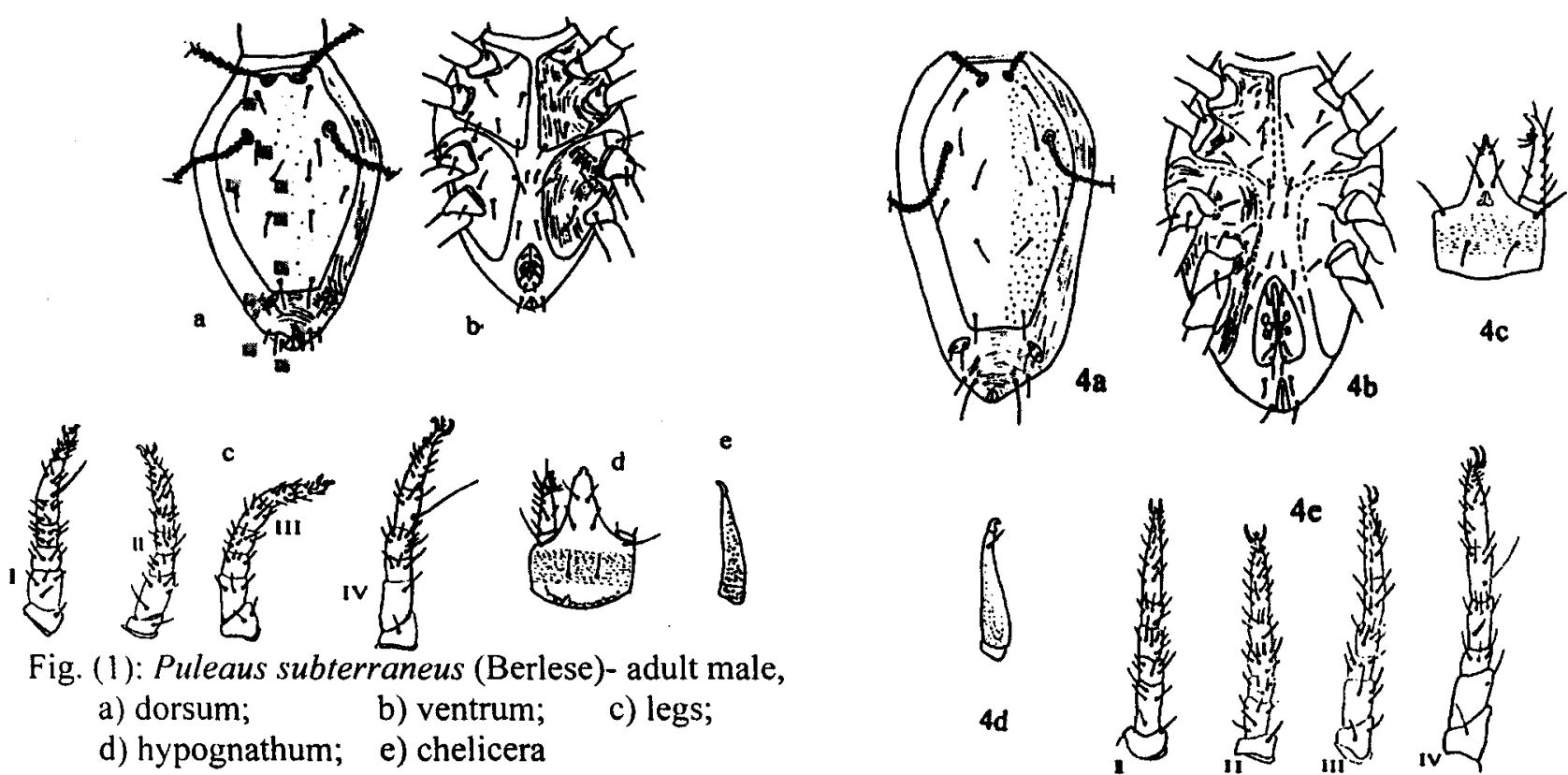

Fig. (1): Puleaus subterraneus (Berlese)- adult male,
a) dorsum;
b) ventrum;
c) legs;
d) hypognathum;
e) chelicera
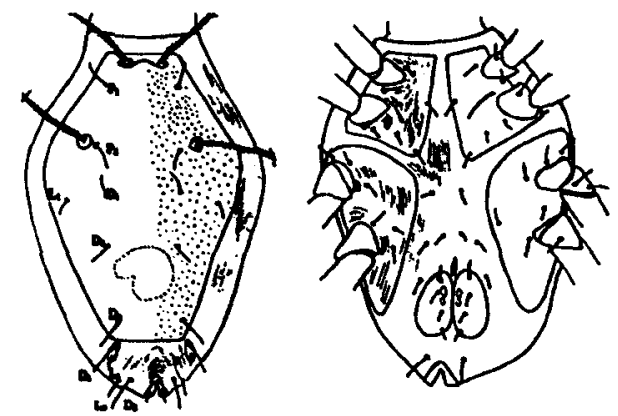

Fig. (2): Dorsum \& ventrum of adult female of Puleaus subterraneus
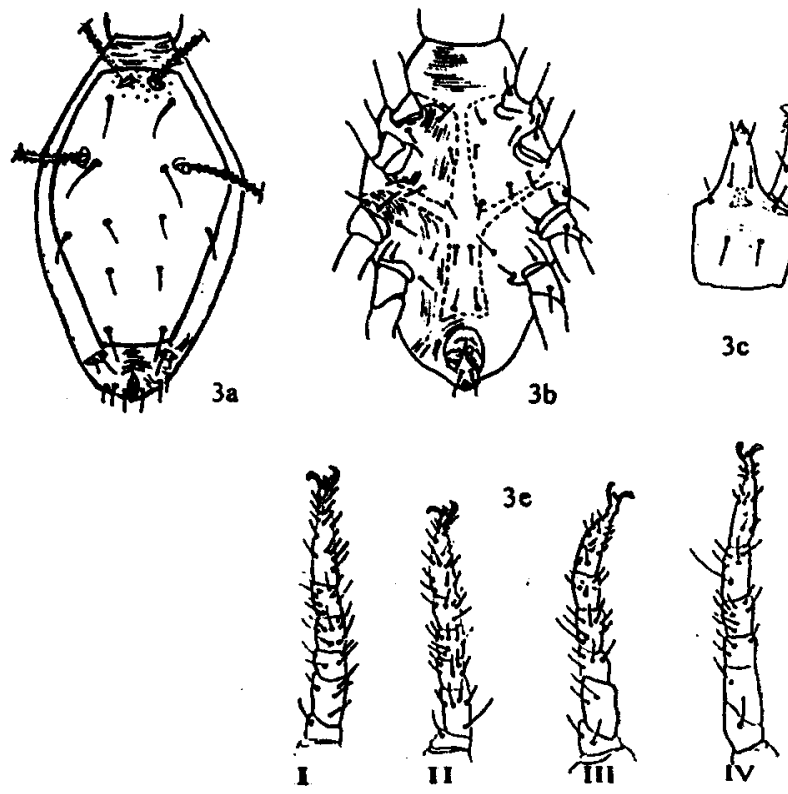

Fig. (3): Male tritonymph of Puleaus subterraneus,
a)dorsum; b) venter;
c) hypognathum;
d) chelicera; e) legs.

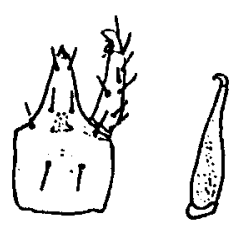

$3 d$
ig.(4): Femal
a) dorsum;
nymph of Pulear
eaus subterraneus,
d) chelicera;
b) venter;
c) hypognathum;
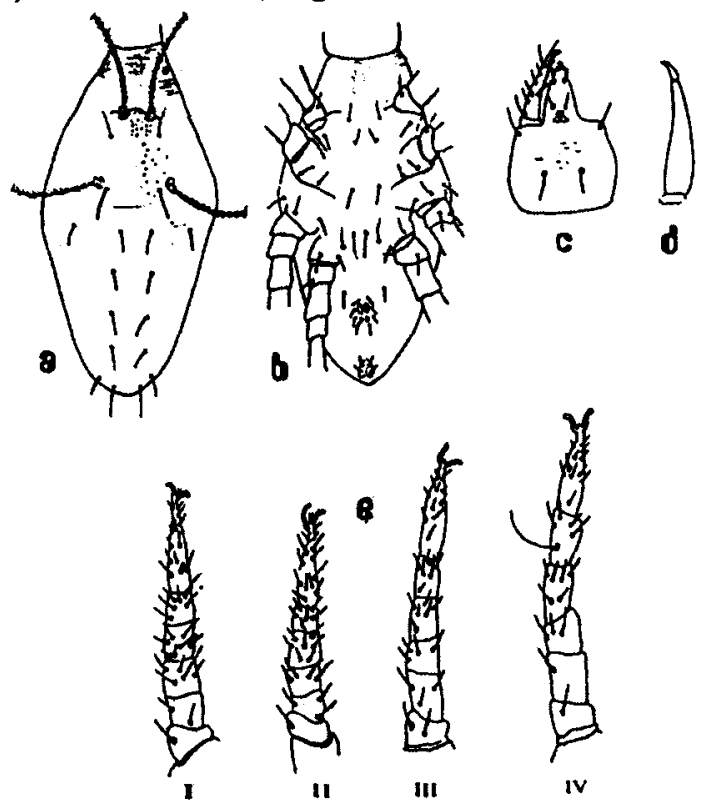

Fig. (5): Deutonymph of Puleaus subterraneus,
a) dorsum;
b) Venter;
c) hypognathum;
d) chelicera; e) legs.

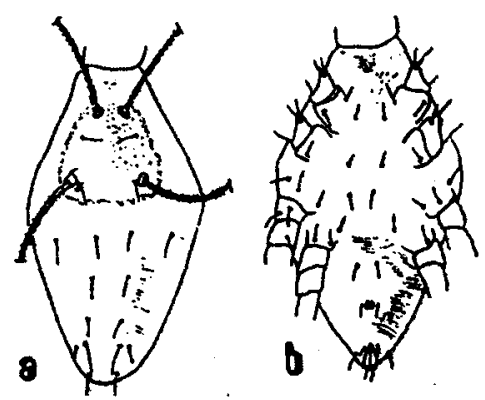

Fig. (6): Protonymph of Puleaus subterraneus,
a) dorsum;
b) Venter. 
Pulaeus subterraneus (Berlese) Den Heyer, 1980: 18; 1981b: 87; Sepasgosarian, 1984: 144. Pulaeus niloticus Zaher \& El-Bishlawy in Zaher 1986: 264.

Diagnosis: The most distinguish structure of this genus is the presence of an elongate balloon-like apophysis and another lateral spine-like in the inner surface of the tibiotarsus, and by having a punctuated dorsal shield.

\section{Description of adult male (Fig. 1)}

Orange red, smooth and brilliant, smaller than adult female (Fig. 2).

Dorsum. Idiosoma covered by a large dorsal plate, with two pairs of anterior and posterior simple setae $\mathrm{P}_{1}-\mathrm{P}_{2}$ and two pairs of anterior and posterior sensillae in the propodosomal region. The hysterosomal region with setae $\mathrm{D}_{1}-\mathrm{D}_{3}$ and $\mathrm{L}_{1}$; setae $\mathrm{D}_{3}$ longer than $\mathrm{D}_{1}-\mathrm{D}_{2}$ and $\mathrm{L}_{1}$; two platelets occur behind the large dorsal plate, each bearing setae $\mathrm{D}_{4}$ and $\mathrm{L}_{4}$; setae $\mathrm{D}_{5}, \mathrm{~L}_{5}$ of each side on the integument, laterally to the anal valves. Dorsal plates smooth and possess subcuticular punctuations; integument around the dorsal plates and anterodorsal to the anus supplied with striation.

Ventrum. Ventral sternal plate divided medially forming two distinct plates, with dense striation pattern as than of the integument, each plate with six setae, Coxae III and IV forming two separate elongate lateral plates each with six setae; anterior part of coxae III producing the prominent shoulders. The integument bearing striations, with two pairs of hysterogastral setae anterior to the genital plates. Genital plates with four pairs of simple setae and two pairs of genital discs; anal region dorsoventrally, with two pairs of para-anal setae; one pair in the dorsum, while the other pair in the venter.

Gnathosoma. The hypognathum longer than broad, attenuate distally, has a transverse striation in the ventral surface, bearing four pairs of hypognathal setae $\mathrm{hg}_{1}-\mathrm{hg}_{4}$, of which hg $g_{3}$ the longest. The dorsal edge of coxal region supplied with papillae; the hypostome relatively short without reticulation; the coxal part of hypognathum provided with subcuticular sculpturings and papillae. Palp three segments, cheatotaxy of palp as follows: Trochanter without setae; femur and genu fused, longer than wide, with five outer lateral simple setae, and one inner lateral simple setae; tibiotarsus characterised by two outer lateral simple setae, one inner lateral simple seta, one balloon-like apophysis and one tooth-like structure on the inner lateral surface and ventrally with two simple setae; tibiotarsus terminating with claw.

Chelicerae. Elongate, located dorsally over the hypostome, consists of three segments, the base short, the blade elongate, strong, broad posteriorly and attenuate anteriorly and the movable digit. which is the chela; the dorsal cheliceral seta laking; segments I and II of chelicerae provided dorsally with papillae.

Legs. Shorter than the idiosoma, tarsi attenuate, end with claws; femora divided into basifemur and telofemur, all segment provided with papillae. Chaetotaxy of legs as follows: coxae I-IV, 3-3-3-3; trochanters I-IV. 1-1-2-1; basifemora I-IV, 4-5-3-1; telofemora I-IV 4-4-4-3; genu I, 3attenuate solenidia +4 , genu II, 2attenuate solenidia +5 , genu III, 1 solenidion +6 , genu IV, I solenidion +6 ; tibia I, I solenidia +4 , tibia II, I solenidion +4 , tibia III, 1solenidion +4 tibia IV, I trichobothria +4 ; tarsus I, 1long basal solenidion +13 , tarsus II, I solinidion +14 , tarsus III, 15, tarsus IV, 12.

\section{Comparison between male and female tritonymph} Male tritonymph (Fig. 3)

Of the same size as the adult male, with the dorsum closely resembles adult while the venter, with the sternal and coxal plates not clearly demarcated and less sclerotised than the adult, with complete chaetotaxy. The gnathosoma longer than wide and differs in the absence of subcuticular sculpturing in the coxal region of hypognathum. Features of legs applicable to those of the adult male except of the absence of the long basal solenidion of tarsus I as shown in (Fig .1c).

Female tritonymph (Fig. 4):

Dorsum similar to male with complete chaetotaxy, but larger in size with weakly sclerotised plates; venter characterized by provided with four coxal groups as in adult (Fig. 2), but without sclerotised plates and distinguished by the striation pattern; the genital valves with four pairs of genital setae and two pairs of genital discs; the anal region dorsoventrally. Also, it differs from male tritonymph by having four pairs of hysterogastral setae in the integument laterally and anteriorly to the genital valves.

Legs. Shorter than the idiosoma. Chaetotaxy of legs as follows: coxae I-IV, 3-3-3-3; trochanters IIV. 1-1-2-1; basifemora I-IV, 4-5-3-1; telofemora IIV 5-5-4-3; genu I, 3attenuate solenidia +4 , genu II, 2 attenuate solenidia +5 , genu III, I solenidion +5 , genu IV, I solenidion +5 ; tibia I, I solenidion +5 , tibia II, 1 solenidion +5 , tibia III, I solenidion +5 tibia IV, I trichobothria +4 ; tarsus I, 2 solenidia +13 , tarsus II, I solinidion +15 , tarsus III, 13 , tarsus IV, 12 .

\section{Deutonymph (Fig. 5)}

Bright orange, smooth and shiny. The whole region of the propodosoma provided with subcuticular punctuation. Dorsum with complete 


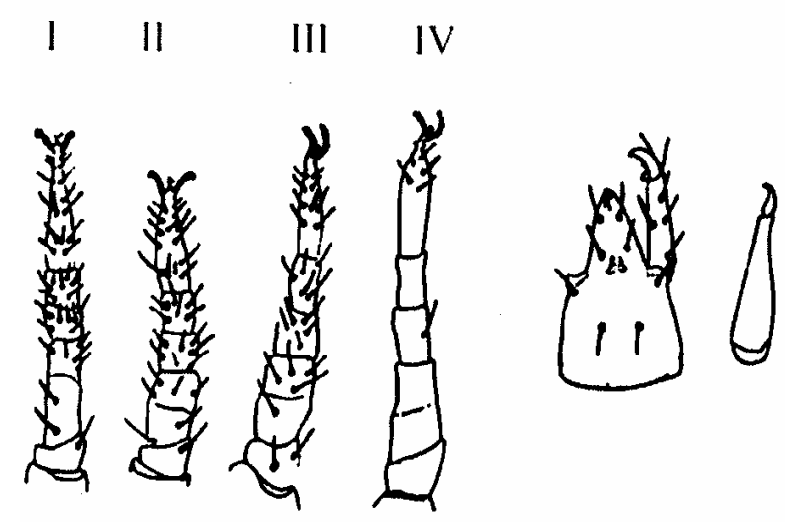

Fig. (7): Hypognathum and chelicera of Pulaeus subterraneus protonymph

chaetotaxy but, setae borne on striated integument. Ventrum differs from that of the adult in the absence of sternal and coxal plates and the anal region located ventrally with two pairs of anal setae; Gnathosoma smaller and less sclerotised, with striated coxal region and four pairs of hypognathal setae. Legs shorter than the idiosoma; leg cheatotaxy as follows: coxae I-IV, 3-2-3-3; trochanters I-IV. 11-2-1; basifemora I-IV, 2-3-3-1; telofemora I-IV 54-4-3; genua I-IV, 7-7-6-6 tibiae I-IV, 6-6-6-5; tarsi I-IV, 15 -15-11-11.

\section{Protonymph (Fig. 6 \& 7)}

Pale orange, dorsal propodosomal region demarcated by integumental striations; the region anterior to sensillae provided with punctuation; hysterosomal region supplied with striations with complete chaetotaxy as in the adult; while venter distinguished by possessing one pair of genital discs, one pair genital setae and one pair of hysterogastral setae; anal opening located ventrally with one pair of anal setae; Gnathosoma similar to that of the adult but, less sclerotic. Legs with the femora not completely divided the chaetotaxy as follows: coxae I-IV, 3-2-3-3; trochanters I-IV. 1-1-2-0; femora I-IV, 7-6-5-0; genua I-IV, 7-7-5-1; tibiae I-IV, 7-6-5-0; tarsi I-IV, 15 -14-9-5.

\section{Larva (Fig. 8)}

Pale orange, spindle in shape, with three pairs of legs; Propodosomal region demarcated by integumental striation, with two pairs of setose sensillae and two pairs of simple setae; hysterosomal region without plate, with complete chaetotaxy, while the venter, with one pair of propodogastral setae and one pair of hysterogastral setae; coxae I \& II characterized by the presence of apodeme; the genital region is laking; anal opening longitudinal with one pair of para-anal setae. Gnathosoma similar to that of the adult but, the palps relatively smaller
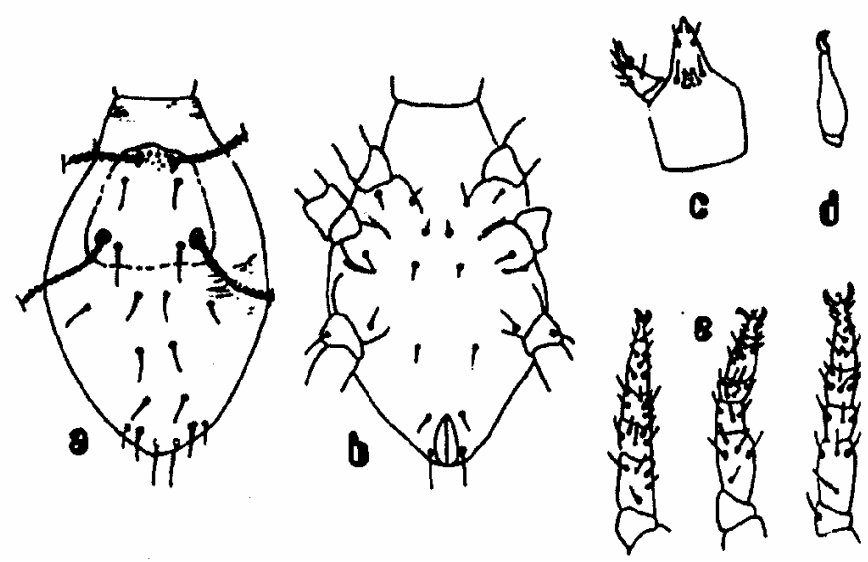

Fig. (8): Larva of Pulaeus subterraneus, a) ventrum; c) hypognathum; d) chelicera; e) legs

and chelicerae less sclerotic; ventral surface of the hypostome with only two pairs of setae $\mathrm{hg}_{1}-\mathrm{hg}_{2}$ while setae $\mathrm{hg}_{3}-\mathrm{hg}_{4}$ laking from coxal region. Legs short, end with attenuate tarsi and two claws; the femora are undivided; caetotaxy as follows: coxae I-III, 3-1-1; trochanters I-III. 0-0-1; femora I-III, 55-4; genua I-III, 5-3-3; tibiae I-III, 6-6-6; tarsi I-III, 9-11-10.

\section{REFERENCES}

Baker, E. W. and Hoffmann, A., 1948. Acaros de la familia Cunaxidae. An. Esc. Nac. Cicnc. Biol. Mex. 5 (3 - 4): 229 - 273.

Berlese, A., 1888. Acari Austro Americani Buos Collegit Alosyius. Balzan .Soc. Entomol. Ital. 20: 188, pl. 7.

Berlese, A., 1916. Centuria Terza di Acari. Redia 12: 289 - 338.

Cooreman, J., 1954. Notes sur quelques Acariens de la faune Cavernicole. Inst.Roy. De Sci. nal. De Belg. Tome XXX (34): 1-18.

Den Heyer, J., 1975. A new genus Cunabdella (Prostigmata: Acari) with a description of a new species from the Ethiopian region. Acarologia 16 (4): 664- 670.

Den Heyer, J., 1979. Coleoscerinae, a new cunaxid subfamily and two new South African species of Coleoscirus Berlese 1916 (Acari: Prostigmata) Acarologia, 20 (4): 522 -54.

Den Heyer, J., 1980. Pulaeus, a new cunaxid genus (Acari: Prostigmata) Acarologia, 21 (1): 18 - 33.

Den Heyer, J., 1981a. Systematic of the family Cunaxidae Thor, 1902. Publ. Univ. of the North Ser. A. 24: 1 -19.

Den Heyer, J., 1981b. Three new Afrotropical species of the genus Pulaeus (Acarida: Actinedida). Phytophylactica 13: 87 - 99. 
El-Khateeb, H. M., 1998. Life tables of some predaceous mites and their importance in biological control. Ph. D. Thesis 119 pp. Fac. Agric. Cairo Univ.

Ghallab M. M., 2002. Ecological, biological and morphological studies on some predaceous mites (suborder: Actin-edida) Ph.D. Thesis Fac. Sc. Cairo Univ. 244 pp.

Khalil, A. M., 2000. Ecological and biological studies on some mites (suborder Actinedida) M.Sc. Thesis Fac. Agric. Al-Azhar Univ. 119 pp.

Nassar, O. A., 1976. Incidence of predaceous mites on fruit trees in North East of Delta with emphasis on Cunaxa setirostris (Hermann). M Sc. Thesis Fac. Agric. Cairo Univ. 91 pp.

Sepasgosarian, H., 1984. The world genera and species of the family Cunaxidae (Acarida: Actinedida) Zeit. Ang. Zool. 71: 135 -150.

Smiley, R. L., 1975. A generic revision of the mites of the family Cunaxidae (Acarina). Ann. Entomol. Soc. Am. 68 (2): 227 -244.
Smiley, R. L., 1992. The predatory mite, family Cunaxidae (Acari) of the world with a new classification. Indira Publishing House, West Bloom Field Michigan USA, 355 pp.

Thor, S. and Willmann, C., 1941. Acarina Prostigmata 6-11 (Eupodidae, Pen-thalodidae, Penthaleidae, Pachig-nathidae, Cunaxidae) Das. Tierreich 71a: 1 -186.

Zaher, M. A., 1986. Survey and ecological studies on phytophagous, predaceous, and soil mites in Egypt. II A Predaceous and non predaceous mites (Nile Valley and Delta) PL 480 Program USA Project No. EG-ARS-30. Grant No. FG-139.

Zaher, M. A., Soliman, Z. R., and El-Bishlawy, 1975. Feeding habits of the predaceous mite Cunaya capreolus Berlese, (Acari-Cunaxidae). Entomo-phaga, 25 (2): 209-212.

Zaher, M. A., A. K. Wafa; M. M. Ali and A. H. Rasmy, 1970. Survey of mites associated with citrus trees in Egypt and Giza Stripe, Bull. Soc. Entomol. Egypt L IV: 73 -79. 